\title{
Response of Rice Genotypes to Arsenic Contaminated Field Condition during Kharif and Boro Season

\author{
Minsura Begum ${ }^{1}$, S. Mondal ${ }^{2}$
}

Department of Plant Physiology, Bidhan Chandra Krishi Viswavidyalaya, Mohanpur, Nadia-741252, West Bengal, India

\begin{abstract}
A study was conducted to evaluate rice germplasm for their arsenic content in different plant parts and phosphorus content in grains. Results showed that in the rice plant highest arsenic was accumulated in the roots and the lowest in the grain. The arsenic accumulation follows the order of root>shoot>leaf $>$ grain. The results also revealed that IRRI dhan was quite tolerant to arsenic and Satabdi 1 was susceptible to arsenic accumulation during kharif season, whereas during boro season IET-4094 accumulated more arsenic in grain and IR-50 accumulated less arsenic in grain. Results also showed that kharif rice genotypes bore strong positive association between total phosphorus percent with arsenic content in grain, whereas strong negative association was found in boro season rice genotypes.
\end{abstract}

Keywords-Arsenic, Rice (oryza sativa L.), phosphorus, West bengal.

\section{INTRODUCTION}

Arsenic is a naturally occurring toxic metalloid and widely distributed in the soil, water, air and all living matters. Anthropogenic activities, including metal smelting, coal combustion, dyes, and hide tanning wastes, chemical weapons and arsenic pesticides have contributed to elevated arsenic in the environment. Large areas of Bangladesh, West Bengal, northwest China and Vietnam have to rely on arsenic-contaminated ground-water for irrigation of staple crops such as rice (Berg et al. 2001, Abedin et al. 2002) and the extensive use of arsenic contaminated groundwater for crop irrigation in the arsenic affected areas as the cause of arsenic poisoning, and possibility of a build-up of arsenic in soils and agronomic and/or horticultural produce, that acts as a conduit for the passage of the toxicant to human population via food-web. Out of the twenty countries in different parts of the world where ground water arsenic contamination and human suffering from there have been reported so far, the magnitude is considered to be the highest in Bangladesh, followed by West Bengal, India. The wide spread arsenic contamination in groundwater in different parts of West Bengal, distributed over 111 blocks, located primarily in twelve districts in West Bengal. The distribution pattern of arsenic among various plant parts is highly variable. Excessive pumping of ground water has increased arsenic toxicity in West Bengal, Bangladesh and many other Asian countries. The arsenic concentration tends to build up from the contaminated groundwater, via the soil, to the crop, irrigated with such water. Adak and Mandal (2000) stated that among the plant parts, arsenic concentration was higher in roots, followed by stems and leaves, in that order, while the economic or edible parts recorded the lowest concentration of the toxin. Phosphorus $(\mathrm{P})$ is one of the essential major plant nutrients for plant growth. Because As and $\mathrm{P}$ are both placed in group $\mathrm{Vb}$, the interaction of As and $\mathrm{P}$ in soil-plant system is an important issue in respect of arsenic mobilization. Several workers showed that the presence of phosphate caused a reduction in arsenate adsorption, and that the reduction was much greater for the competitive effects of arsenate on phosphate adsorption by soil minerals, although a large variation in the degree of competition between these two oxyanions has also been reported (Kuo and McNeal, 1984; Mukhopadhyay and Sanyal, 2002). Inorganic arsenic is highly toxic to plants because it uncouples phosphorylation and inhibits phosphate uptake. Arsenate is taken up by plants via the phosphate $(\mathrm{Pi})$ transport systems because of similarity between arsenate and $\mathrm{Pi}$ and after entering plant; arsenate might interfere the phosphate metabolisms and caused toxicity of plant (Dixon, 1997)

In the above circumstances the present study was undertaken to see the concentration of arsenic in different parts and genotypes of rice and the relationship between arsenic in different parts and grain phosphorus.

\section{MATERIALS AND METHODS}

Plant samples were collected from farmer's field at Nonaghata-Uttarpara, Haringhata block, Nadia, West Bengal. Rice samples were collected by composite sampling from the arsenic affected fields.

\subsection{Analysis of the total arsenic in plant sample}

The rice plant samples were washed thoroughly with tap water to remove soil and other contaminants and finally rinsed with de-ionised water with continuous shaking for several minutes. The samples were then dried in the Hot Air Oven at 60C for 72 hours. Root, shoot, leaf and grain from the rice plant sample were digested separately in an Erlenmeyer flask by a mixture 
of concentrated acids, e.g., $\mathrm{HNO}_{3}, \mathrm{HClO}_{4}$ and $\mathrm{H}_{2} \mathrm{SO}_{4}$ in a proportion of 10:4:1 (v/v). After an overnight reaction, the content of the flask were gently boiled on an electric heater for digestion. The entire digestion process lasted 3-4 hours. After complete digestion, the solution was diluted with double distilled water and filtered by Whatman No. 42 filter paper and transferred in to acid-washed plastic bottle; this solution was used for analyzing the arsenic and phosphorus content of the sample. Each treatment was performed in triplicate. The digest was diluted to $50 \mathrm{ml}$. Ten (10) $\mathrm{ml}$ of the aliquot was taken in $50 \mathrm{ml}$ plastic tube, $5 \mathrm{ml}$ of concentrated $\mathrm{HCl}$ and $1 \mathrm{ml}$ of each of reagent $5 \% \mathrm{KI}(\mathrm{w} / \mathrm{v})$ and $5 \%$ Ascorbic acid (w/v)] were mixed, kept for 45 minutes to ensure complete reaction. Now the volume was made up to $50 \mathrm{ml}$ and the resultant solution was analyzed in a Perkin-Elmer Atomic Absorption Spectrophotometer with Flow Injection Analysis System (FIAS 400) @ $\lambda_{\max } \cong 193.7 \mathrm{~nm}$ where the carrier solution was $10 \% \mathrm{v} / \mathrm{v} \mathrm{HCl}$, the reducing agent (to ensure all As species be reduced to $\mathrm{AsH}_{3}$ and to be measured against a calibration with standard $\mathrm{As}^{+3}$ solution) was $0.2 \% \mathrm{NaBH}_{4}$ in $0.05 \% \mathrm{NaOH}$ (Welsch et al,1990).

Phosphorus content in plant sample (grain) was determined by following the vanadate molybdate yellow colour outlined by Jackson (1973).

Statistical Data analysis: Pearson's correlation coefficient was carried out to find out the correlation among arsenic concentration in different parts (root, shoot, leaf and grain) and total Phosphorus in grains by SPSS software, version 14.0 for windows (SPSS Inc., Chicago, USA)

\section{RESULTS AND DISCUSSION}

The values of arsenic concentration in grains, roots, stems and leaves of kharif rice crop of the genotypes are presented in Table 1. Arsenic concentration of roots, shoots, leaves and grains of the genotypes ranged between 2.958 to $9.475,1.004$ to 4.510, 0.973 to 4.773 and 0.180 to1.960.The variation in root, shoot, leaf and grain arsenic concentration among the rice genotypes was statistically significant indicating inherent difference among the genotypes in this regard. The highest root, shoot, leaf and grain As concentration was observed in satabdi 2 (9.475), Minikit (4.510), Minikit (4.773), satabdi 1 (1.960), whereas, the lowest root, shoot, leaf and grain As concentration was recorded in GS-3 (2.958), satabdi 2 (1.004), Satabdi 2(0.973), IRRI dhan (0.180). So, it was observed that IRRI dhan accumulated less arsenic in grain and Satabdi1 accumulated more arsenic in grain. Total P \% of grain ranged between 0.412 and 0.124 . The highest total phosphorus $\%$ was observed in GS-2 (0.412), the lowest total phosphorus \% was recorded in IRRI dhan (0.124).

TABLE 1

ARSENIC CONCENTRATIONS IN ROOT, SHOOT, LEAF AND GRAIN (mg/kg) ALONG WITH GRAIN PHOSPHORUS CONCENTRATION OF THE RICE GENOTYPES GROWN DURING KHARIF

\begin{tabular}{|c|c|c|c|c|c|c|}
\hline S. No & Cultivar & Root As & Shoot As & Leaf As & Grain As & Total P\% \\
\hline 1 & IET- 4786 & 4.378 & 3.255 & 2.305 & 0.340 & 0.222 \\
\hline 2 & MTU 7029 & 5.125 & 3.628 & 2.640 & 0.380 & 0.230 \\
\hline 3 & Jal kumara & 8.530 & 2.565 & 3.778 & 0.511 & 0.245 \\
\hline 4 & Ranjit & 3.875 & 1.745 & 2.583 & 0.230 & 0.173 \\
\hline 5 & Kakdwip sel-15 & 4.353 & 2.050 & 2.550 & 0.420 & 0.212 \\
\hline 6 & IRRI dhan & 3.275 & 2.031 & 1.260 & 0.180 & 0.124 \\
\hline 7 & GS-3 & 2.958 & 2.373 & 1.008 & 0.340 & 0.214 \\
\hline 8 & Kakdwip sel-7 & 5.890 & 4.178 & 1.320 & 0.240 & 0.154 \\
\hline 9 & Ratna & 3.710 & 1.073 & 1.160 & 0.290 & 0.200 \\
\hline 10 & IET-4094 & 6.270 & 1.120 & 3.020 & 0.570 & 0.211 \\
\hline 11 & Nayanmoni & 4.250 & 1.060 & 2.120 & 0.460 & 0.247 \\
\hline 12 & Satabdi 1 & 6.070 & 3.625 & 3.175 & 1.960 & 0.236 \\
\hline 13 & Minikit & 7.685 & 4.510 & 4.773 & 1.483 & 0.215 \\
\hline 14 & IET-4787 & 7.413 & 1.651 & 1.042 & 0.681 & 0.213 \\
\hline 15 & Satabdi 2 & 9.475 & 1.004 & 0.973 & 0.500 & 0.222 \\
\hline 16 & GS-2 & 7.523 & 2.156 & 2.630 & 1.634 & 0.412 \\
\hline 17 & GS-1 & 3.714 & 3.808 & 2.040 & 0.480 & 0.253 \\
\hline & Mean & 5.559 & 2.461 & 2.258 & 0.629 & 0.223 \\
\hline & SEm \pm & 0.066 & 0.057 & 0.050 & 0.028 & 0.006 \\
\hline & CD (P= 0.05) & 0.192 & 0.166 & 0.143 & 0.079 & 0.017 \\
\hline
\end{tabular}


TABLE 2

ARSENIC CONCENTRATIONS IN ROOT, SHOOT, LEAF AND GRAIN ALONG WITH GRAIN PHOSPHORUS CONCENTRATION OF THE RICE GENOTYPES GROWN DURING BORO

\begin{tabular}{|c|c|c|c|c|c|c|}
\hline SI.No. & Cultivar & Root & Shoot & Leaf & Grain & Total P\% \\
\hline 1 & IRRI dhan & 4.100 & 2.120 & 0.765 & 0.340 & 0.275 \\
\hline 2 & Satabdi & 7.100 & 3.930 & 1.110 & 0.650 & 0.245 \\
\hline 3 & GS-1 & 6.100 & 2.030 & 0.643 & 0.363 & 0.260 \\
\hline 4 & Jaldi minikit & 7.480 & 1.810 & 2.340 & 0.453 & 0.230 \\
\hline 5 & IR-50 & 7.430 & 2.500 & 3.330 & 0.330 & 0.245 \\
\hline 6 & GS-3 & 7.430 & 2.070 & 2.880 & 0.985 & 0.258 \\
\hline 7 & IET-4094 & 6.550 & 2.900 & 0.753 & 1.890 & 0.200 \\
\hline \multicolumn{2}{|c|}{ Mean } & 6.599 & 2.480 & 1.689 & 0.716 & 0.245 \\
\hline \multicolumn{2}{|c|}{ SEm \pm} & 0.091 & 0.059 & 0.036 & 0.012 & 0.011 \\
\hline \multicolumn{2}{|c|}{ CD $\mathbf{0 . 0 5})$} & 0.282 & 0.181 & 0.110 & 0.036 & 0.034 \\
\hline
\end{tabular}

Table 2 represents the arsenic concentration in grains, stems, leaves and roots of the rice genotypes grown during boro season in the arsenic contaminated situation. Arsenic concentration of root, shoot, leaf and grain ranged between 7.480 and 4.100 , 3.930 and 1.810, 3.330 and $0.643,1.890$ and 0.330 . The variation in root, shoot, leaf and grain arsenic concentration among the rice genotypes grown during boro season was statistically significant indicating inherent difference among the genotypes in this regard. The highest root, shoot, leaf and grain As concentration was observed in Jaldi Minikit (7.480), Satabdi (3.930), IR-50 (3.330), IET-4094 (1.890), the lowest root, shoot, leaf and grain was recorded in IRRI dhan (4.100), Jaldi minikit (1.810), GS-1 (0.643), IR-50(0.330). It was recorded that IET-4094 accumulated more arsenic in grain and IR-50 accumulated less arsenic in grain. The results showed that arsenic accumulated mostly in the root of rice plant followed by accumulation in shoot, leaf and lowest in grain. These findings are in agreement with the findings of Rahman et al. (2007). Higher accumulation of arsenic in root of the rice plant might be due to formation of iron oxides around the rice root, which bind the arsenic and reduce its translocation to the above ground tissues of the plant. Total $\mathrm{P} \%$ of grain ranged between 0.275 and 0.200 . The higher accumulation of total $\mathrm{P} \%$ of grain was observed in IRRI dhan (0.412), the lower accumulation was recorded in IET-4094 (0.200).

TABLE 3

CORRELATIONS CO-EFFICIENT BETWEEN ARSENIC CONCENTRATIONS OF DIFFERENT PLANT PARTS DURING KHARIF SEASON

\begin{tabular}{|c|c|c|c|c|c|c|}
\hline Sl.No. & $\mathbf{1}$ & $\mathbf{2}$ & $\mathbf{3}$ & $\mathbf{4}$ & $\mathbf{5}$ & $\mathbf{6}$ \\
\hline 1 & Character & Root As & Shoot As & Leaf As & Grain As & Total P \\
\hline 2 & Root As & - & 0.116 & 0.238 & $0.399(* *)$ & $0.340\left(^{*}\right)$ \\
\hline 3 & Shoot As & & - & $0.362(* *)$ & .139 & 0.079 \\
\hline 4 & Leaf As & & & - & $0.523(* *)$ & 0.245 \\
\hline 5 & Grain As & & & & - & $0.564\left(^{* *}\right)$ \\
\hline 6 & Total P & & & & & - \\
\hline
\end{tabular}

** Correlation is significant at the 0.01 level (2-tailed).

* Correlation is significant at the 0.05 level (2-tailed).

The results revealed that when grain arsenic concentration in the kharif season increases total phosphorus content also increases and in boro rice genotypes when the concentration of total phosphorus increased grain arsenic concentration decreased significantly. Abedin et al. (2002) reported that the uptake rate in rice at $0.05 \mathrm{mM}$ of arsenate decreased significantly $(\mathrm{p}, 0.001)$ with increasing phosphate concentration present in the incubating solution. Opposite results were reported by $\mathrm{Tu}$ and $\mathrm{Ma}$ (2003) that there was a positive correlation between plant phosphate and arsenic concentration in brake fern. The values of correlation co-efficient (table 3) among root, stem, leaf and grain arsenic concentration show that grain arsenic concentration of the rice genotypes grown in contaminated situation during Kharif season bore strong association with arsenic concentration of leaf and root and grain $\mathrm{P}$ concentration. Stem arsenic concentration, though appeared to have no bearing with grain arsenic concentration, found to be associated with leaf arsenic concentration. Root arsenic concentration was observed to be associated with grain $\mathrm{P}$ concentration of the rice genotypes. The values of correlation co-efficient (table 4) among root, stem, leaf and grain arsenic concentration show that grain arsenic concentration 
of the rice genotypes grown in contaminated situation during boro season bore strong negative association with grain $\mathrm{P}$ concentration only. Root arsenic concentration of the boro crop of the genotypes, though appeared to have no bearing with grain arsenic concentration, found to be associated with leaf arsenic concentration.

\section{TABLE 4}

CORRELATIONS CO-EFFICIENT BETWEEN ARSENIC CONCENTRATIONS OF DIFFERENT PLANT PARTS DURING BORO SEASON

\begin{tabular}{|c|c|c|c|c|c|c|}
\hline Sl.No. & $\mathbf{1}$ & $\mathbf{2}$ & $\mathbf{3}$ & $\mathbf{4}$ & $\mathbf{5}$ & $\mathbf{6}$ \\
\hline 1 & Character & Root As & Shoot As & Leaf As & Grain As & Total P \\
\hline 2 & Root As & - & 0.174 & $0.615(* *)$ & 0.165 & -0.328 \\
\hline 3 & Shoot As & & - & -0.263 & 0.291 & -0.231 \\
\hline 4 & Leaf As & & & - & -0.195 & -0.003 \\
\hline 5 & Grain As & & & & - & $-0.551(* *)$ \\
\hline 6 & Total P & & & & & - \\
\hline
\end{tabular}

** Correlation is significant at the 0.01 level (2-tailed).

* Correlation is significant at the 0.05 level (2-tailed).

\section{CONCLUSION}

From the above discussion, it can be concluded that, arsenic concentration in different parts of plant was observed to be in the order of root $>$ stem $\geq$ leaf $>$ grain in both kharif and boro crop of the rice genotypes. Grain As was found to be strongly and positively associated with grain phosphorus, leaf As and root As in kharif crop where as strongly and negatively associated with grain phosphorus only in boro crop.

\section{REFERENCES}

[1] Abedin, M. J., Cottep-Howells, J. and Meharg, A. A. 2002. Arsenic uptake and accumulation in rice (Oryza sativa L.) irrigated with contaminated water. Plant and Soil., $240: 311-319$.

[2] Adak, S. K. and Mandal, B. K. 2000. Influence of arsenic contaminated irrigation water on yield vis-à-vis uptake in different plant parts. Proc. Intl. Conf. on Managing Natl. Resources for sustainable agricultural Production in the $21^{\text {st }}$ Century, New Delhi, February 14-18, 2000. Extended Summaries, Vol. 2, p. 537.

[3] Berg, M., Tran, H. C., Nguyen, T. C., Pham, H. V., Schertenleib, R. and Giger, W. 2001. Arsenic contamination of groundwater and drinking water in Vietnam: a human health threat. Environ. Sci. Tech., 35: 2621-2626.

[4] Dixon, H. B. F. 1997. The biochemical action of arsenic acids especially as phosphate analogues. Adv. Inorg. Chem., 44: 191-227.

[5] Jackson, M.L. 1973. Soil chemical analysis. Prentice-Hall of India Private Ltd., New Delhi.

[6] Kuo, S. and McNeal, B. L. 1984. Effects of $\mathrm{pH}$ and phosphate on cadmium sorption by a hydrous ferric oxide. Soil Sci. Am. J., 48: 1040-1044.

[7] Mukhopadhyay, D and Sanyal, S. K. 2002. Studies on arsenic transport across and down some soils of West Bengal. J. Indian Soc. Soil Sci., 50: 456-463.

[8] Rahman, M. A., Hasegawa, H., Rahman, M. M., Islam, M. N., Miah, M. A. M. and Tasmen, A. 2007. Effect of arsenic on photosynthesis, growth and yield of five widely cultivated rice (Oryza sativa L.) varieties in Bangladesh. Chemosphere., 67: 10721079.

[9] Tu, C., Ma, L. Q., 2003. Effects of arsenate and phosphate on their accumulation by an arsenic- hyperaccumulator Pteris vittata L. Plant Soil 249, 373-382.

[10] Welsch, F. P., Crock, J.G. and Sanzolone, R.1990. Trace elements determination of arsenic and selenium using continous flow hydride generation atomic absorption spectrophotometry (HG-AAS). In Quality Assurance Manual for the Branch of Geochemistry, Ed., Arbogast, B. F.,pp:38-45. 